University of Northern lowa

UNI ScholarWorks

Faculty Publications

Faculty Work

2001

\title{
Abbott $\mathrm{H}$. Thayer's Anticipation of a Computer-Based Method of Working
}

Roy R. Behrens

University of Northern lowa

Let us know how access to this document benefits you

Copyright (C)2001 The MIT Press

Follow this and additional works at: https://scholarworks.uni.edu/art_facpub

Part of the Art and Design Commons

\section{Recommended Citation}

Behrens, Roy R., "Abbott H. Thayer's Anticipation of a Computer-Based Method of Working" (2001).

Faculty Publications. 6.

https://scholarworks.uni.edu/art_facpub/6

This Article is brought to you for free and open access by the Faculty Work at UNI ScholarWorks. It has been accepted for inclusion in Faculty Publications by an authorized administrator of UNI ScholarWorks. For more information, please contact scholarworks@uni.edu. 


\title{
Abbott H. Thayer's Anticipation of a Computer-Based Method of Working
}

\author{
Roy R. Behrens
}

I blance between two otherwise different approaches to artmaking. The first is an unusual painting method that was used about 80 years ago by Abbott H. Thayer (1849-1921), who was then a well-known painter. He may have invented it. The second is a procedure that is now commonly used to create artworks, designs or other results, using personal computers and a wide variety of software.

\section{THAYER'S METHOD}

Thayer was an artist, teacher and naturalist from Dublin, New Hampshire. In recent years, there has been renewed interest in his paintings because of the current popularity of angelsThayer often portrayed women as angels in his paintings. Others find of significance his early, influential work in the area of protective coloration in nature and its subsequent application to military camouflage. He was also an influential teacher, counting among his students the book illustrator Rockwell Kent, scientific illustrator Louis Agassiz Fuertes, and the sons of William James, Alexander and William [1].

When Thayer began a new painting, he preferred to work on it for only 3 days, because, in his words, "all my successes come, as it were, out of the side of my eye, or rather come in the first three days." He had gradually learned, he said, "that I really have nothing but three days powers," and beyond that, he either accomplished nothing or spoiled the painting by overworking it. As a result, he devised a strategy of asking his students to make exact copies of his in-process paintings, during which time he would "paint something else, or go up to Monadnock [a mountain near his home], or write on birds, anything, to get me as far as possible from my work." Returning to his studio, he would then "pounce on a copy and give it a three-day shove again" [2].

As a result of this procedure, Thayer would end up with alternate finished versions of the same painting. While these were collaborative efforts by him and his students, he regarded such works "as his own, in the manner of a Renaissance master" [3]. At the same time, there were other canvases that he and only he could touch, which he sold to his preferred patrons.

It is interesting that the Spanish artist Pablo Picasso, who was 32 years younger than Thayer, with a vastly different idea of art, expressed the desire to use a comparable method. However, there is no indication that he actually used it, nor is it likely that he knew of Thayer's method.

Roy R. Behrens (artist, writer, teacher), 2022 X Avenue, Dysart, IA 52224-9767, U.S.A. E-mail: <ballast@netins.net>
In a collection of Picasso's comments about art, he is reported to have said: "I'm treading very gently. I don't want to spoil the first freshness of my work. If it were possible, I would leave it as it is, while I began over and carried it to a more advanced state on another canvas. Then I would do the same thing with that one. There would never be a 'finished' canvas, but just the different 'states' of a single painting, which normally disappear in the course of work" [4].

\section{COMPUTER-BASED METHOD}

As an artist, designer and teacher, I have been working with Macintosh computers since the 1980s, creating examples of art and graphic design, including digital collages and page layouts. Prompted by software options, my design colleagues at the University of Northern Iowa (Philip Fass and Osie Johnson), our students and I have used for years a work method that reminds me now of Thayer's, although I had not thought about the connection until recently.

In our method, we work on a new project for an undetermined amount of time, ranging from a few minutes to several days. At some point in the process, when we are no longer certain about the direction in which to continue, we pause and create copies by executing a SAVE AS command. Without any assistance from collaborators, we can make as many identical copies as we desire. Then, as did Thayer, we can "pounce" separately on any or all of the copies, giving each "a shove" in a different direction (Fig. 1). All the while, we are careful to preserve at least one copy of the work at the time that we paused and made copies.

We prefer to use the SAVE AS command rather than to save the file as a template because, depending on the software, it may not be possible to modify the starting point of a template. In using the SAVE AS command, one can embark on alternatives from the same point of departure, as in a template, but with the option of freely reverting to an earlier, less elaborate state.

This insight may seem trivial, and it surely is in the sense that this process is probably used, independent of our efforts, by artists, designers and others throughout the world [5]. It may also seem trivial because the quality of the end result is in no way guaranteed. At the same time, the method has several advan- 

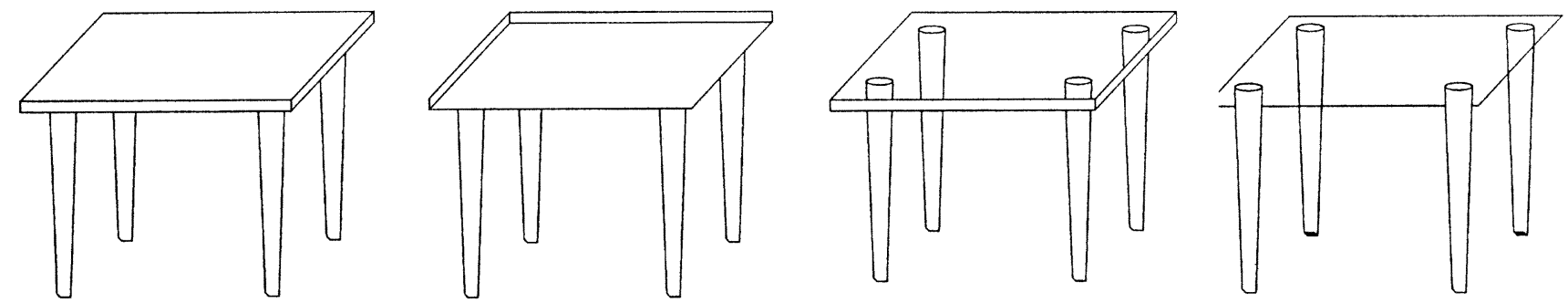

Fig. 1. Four stages in the process of designing a digital artwork by Philip Fass, using Adobe Illustrator software. (@ Philip Fass) At the first stage (left, the drawing of a conventional table), the artist paused and made copies using the SAVE AS command. The three remaining images are alternative subsequent stages, each of which uses a different strategy (manipulation, addition, subtraction) to arrive at distinctive versions.

tages. The most obvious is that we are less likely to ruin a work by taking it in a direction that is not retractable. As a result, we are less apprehensive about the creative process, and far more willing to invent. "It is," as Thayer described it, "like keeping one foot always planted firm as one climbs a dangerous cliff. ..." [6]

A further advantage of the process is that it enables us to look at a number of alternate versions side by side (whether on the computer screen or as page printouts), and to use comparative "visual thinking" in assessing the value of what we have done [7].
Finally, as with Thayer, our method may also result in two or more versions of the same work of equal quality.

\section{References and Notes}

1. Regarding Thayer's life and work, see Nelson C. White, Abbott H. Thayer: Painter and Naturalist (Hartford, CT: Connecticut Printers, 1951); Ross Anderson, Abbott Handerson Thayer, exh. cat. (Syracuse, NY: Everson Museum, 1982); Roy R. Behrens, "The Theories of Abbott H. Thayer: Father of Camouflage," Leonardo 21, No. 3, 291-296 (1988).

2. Letter from A.H. Thayer to Thomas W. Dewing, c. 1917, in the Archives of American Art, Smithsonian Institution, Washington, D.C. (Thaye Papers, Microfilm Roll D200, Frame 1134). Quoted in Anderson [1] p. 27.
3. Anderson [1] p. 27.

4. Quoted in Dore Ashton, Picasso on Art: A Selection of Views (New York: Viking Press, 1972) p. 31.

5. I am grateful to an anonymous reviewer for pointing out that, in a wider sense, methods anticipating Thayer's and ours have been used for centuries, far in advance of computers. Multiple copies of the same starting point were made possible by a variety of devices, such as the drawing machines employed by Leonardo da Vinci and Albrecht Dürer, the camera obscura, the camera lucida and photography.

6. Thayer [2]

7. See Rudolf Arnheim, Visual Thinking (Berkeley, CA: Univ. of California Press, 1969).

Manuscript received 24 March 2000. 